\title{
Different Forms of Rationalities in Aristotle: From Being to Acting
}

\begin{abstract}
Nadir Antonio Pichler
University of Passo Fundo

Every philosophical system of Aristotle is structured around different forms of rationalities. Each form of rationality, according to its method, object, and purpose, seeks to apprehend and to know a specific dimension of being, because being manifests itself in many ways, that is, the totality of reality. Yet, each form of understanding the being has its epistemological and ontological status, always anchored in the logic criteria. In general, the aim of the paper is to characterize some aspects of the main forms of rationalities in the thought of Aristotle, i.e., demonstrative, dialectic, physics, metaphysics, productive, and practices. But before that, succinctly, it is necessary to talk about the different dimensions of being and teleology.

Keywords: forms of rationales, teleology, being
\end{abstract}

\section{Introduction}

Aristotle, in his philosophical system, has different ways or forms of rationales to try to understand, in breadth and depth, the multiple manifestations of being, i.e., the totality of reality. Each form of rationality, according to his method, object, and scope, seeks to seize and express a dimension of being. Each form of rationality has its epistemological and ontological status, always permeated by the logic criteria.

For doing so, we follow two fundamental criteria used by the stagirit. First: Every previous cultural tradition should be considered, but not necessarily accepted, because each time period has its specificities. Hence, the need to visit the tradition critically, unraveling it, trying to draw from it what is useful to science in vogue. Second: Every philosophical research should seek to understand the world from the simple things, from the closest through the sensation, to the most complex, the furthest to the senses seized only by the nous, the intelligence.

In general, the aim of the paper is to characterize some aspects of the main forms of rationalities in the thought of Aristotle, i.e., demonstrative, dialectic, physics, metaphysics, productive, and practices. But before that, succinctly, it is necessary to talk about the different dimensions of being and teleology.

\section{From Being to Knowing and Acting}

Aristotle knows deeply the previous philosophical tradition. His stay at the Academy granted him access to the topos of knowledge of the Hellenistic world. His desire for knowledge and a sound financial condition, made him acquire all the books available at the time. After all, "all men, by nature, desire to know" (Met. The 1, 980 a). The anthropological natural tendency of man to know is the root from which the Aristotelian philosophy

Nadir Antonio Pichler, Dr., Prof., Department of Philosophy, University Passo Fundo, Brazil; main research fields: Ontology. 
is born and based on, particularly, philosophy, and metaphysics. And the search for wisdom is the specific excellence of the wise. And this wisdom is the product of research in various areas of knowledge, seminars, and discussions made at the Academy and Lyceum, without disregarding personal reflection and contemplation of the knowledge acquired. From this diversity of approaches to being, Aristotle seems to extract the multiple meanings of being, forms of rationality and hence the different methods and the statutes of the different sciences.

Therefore, it distinguishes, in general, three types of knowledge: "All rational knowledge is either practical or productive or theoretical” (Met. E 1, 1025 b). Thus the theoretic sciences, formed by physics, mathematics and metaphysics, seek knowledge for knowledge; practices, economics, ethics, and politics, seek knowledge in terms of moral and political action in the polis; productive, poetics and rhetoric, aimed at knowledge due to do the producing, modernly called "techne" (technical).

In addition to this general characterization of forms of rationalities, it is significant to point out the intrinsic teleological character to the classification of sciences.

According to cosmocentric conception of the Ancient world, man and nature merge in a teleologically-whole horizon, albeit in different planes and with subordinate purposes, being the ultimate goal or the supreme good of man is eudaimonia or happiness. The very movement of life, from its lowest levels, as the inorganic world, starts harmonizing teleologically, increasingly in higher and more perfect forms, reaching for the man, the last horizon, which, by knowledge, takes possession of and gives meaning to the universe. In reality, the man is the end, crown and fulfillment of the entire sensible world. The cosmos without man would be no teleological reason for being and existing. It is the man who gives meaning, content, and unity to the universe. And the man, because of his intellectual capacity, seeks to understand the different manifestations of the real, of being. Thus, in this conception, purpose, teleology is the common thread and interpretation of all reality (Barnes 1982).

\section{Rationalities of Knowledge and Being}

Even being in Aristotle is not reduced to a specific genre, originally it is divided into genres. And if there are many sciences, it is because the being or substance is manifested in different ways. As mathematics has many members, and all are due to a first science, which is the geometry, so the philosophy has parts and heads to the supreme science, metaphysics (Met. D 2, 1004).

\subsection{The Demonstrative Science}

The form of demonstrative or apodictic rationality is developed by Aristotle in the Posterior Analytics. While the First Analytical describes the syllogism in general, the Posterior analyzes the particular syllogism, characterized scientific or demonstrative.

The demonstrative science is also known as a deduction. That is, in the strict sense it means to start from universal premises to reach particular conclusions. "It's what gives science the knowledge of cause and the character of knowledge endowed with need” (Berti 2002, 6).

The principles or assumptions in the demonstrative knowledge try to demonstrate how being or reality is, how it stands. Hence, the need for them to be true, first and immediate, always prior to conclusions. Moreover, the principles are always indemonstrable, otherwise would be return to infinity. Two examples of principles: (a) Own divided into science seeking the definitions of reality, as the discourses that seek to characterize "what is" 
one thing, that is, the essence, and assumptions, discourses that seek to tell if something is and it's not. It is the "if," that is, if there is and there is not a thing. These principles are needed for some science and only for them, such as arithmetic and geometry; (b) Common or axioms are principles for all sciences, such as non-contradiction, that is, it is impossible to simultaneously affirm and deny the same predicate of the same subject and the excluded, i.e., it is necessary to state or deny certain right predicate subject (Sec. An. I 11, 76 b, 77 a).

The demonstrative science, due to the depth achieved by its knowledge, is only taught through monologue.

\subsection{Dialectical Science}

In addition to the apodictic science dealt with Organon, to another form of rationality theorized by Aristotle, dialectic is dedicated to the treaties of topics and sophistical Refutations.

While demonstrative rationality is configured around the monologue, dialectics requires, of course, dialogue. And to have dialogue it is necessary at least two parties to discuss about a particular reality of human praxis, i.e., one proposes and supports a thesis and the other seeks to challenge it. Thus, the assumptions, reasoning, and conclusions on which the dialectic structure is always in the sense of a speech possibilities adjustments between Endoxa, that is, opinions generally accepted by all men, by most or some, most notable and imminent-philosophers (Top 1 I, 100 b). Endoxa does not mean any opinions, but the most accepted premises and most important, able to support in achieving rationality in search of consensus, necessary in deliberative (assemblies), judicial (court), and celebrative (public religion) genres.

Therefore, the discussion engendered by the dialectical syllogism, Aristotle identifies four kinds of speeches:

(a) Didascalic: These are arguments starting from the very principles of certain sciences and not the views of listeners. It requires the listener to predispose on relying on the arguments presented by the speaker or teacher. Even though dialectical, are speeches that resemble the apodictic monological rationality. They are essentially didactic and used in the teaching process. This form of rationality favors passive dialogue, because the listener is set in an epistemic world initially unknown.

(b) Dialectic: These are the arguments used to refute the contradictions identified in reasoning from endoxas, of the generally accepted views.

(c) Peirastic: These are arguments that depart from opinions issued by the interlocutors. Therefore, it is necessary to know the techniques of speeches delivered by the parties to have the property to examine them, trying to identify its contradictions. This discourse genre has traditionally been used by Socrates, and aimed to examine its validity, i.e., those parties or authorities who presumed to be knowledgeable but were actually ignorant.

(d) Eristic: These are speeches that are as party point the apparent opinions, chains, but not real. So Aristotle considers eristic a bad imitation of the dialectic, because it is structured around the immediate premises, that is, with little or no scientific basis, as it does not aim on critically examining a thesis (Arg. Zeph. 2, 165 a).

\subsection{Physical Science}

Andronicus of Rhodes, the critical editor of the works of Aristotle, in the first century, after the collection called Organon presents the treaty of Physics. After Physics come the treaties of cosmology, psychology, 
biology, zoology, and all natural sciences, such as meteorology. Finally comes the Metaphysics, because in it Aristotle investigates the supreme and divine realities which come after physics.

The specific object of physical rationality is to investigate the causes and the first principles of nature, that is, the closer and more evident reality to man, and the man is a member of this nature (Ross 1987, 72). It is worth remembering that physics, as epistemological status, fits in the overall classification of the sciences, within the theoretic sciences.

\subsection{The Metaphysical Rationality}

As we have seen, Aristotle states that all knowledge is practical, productive, and theoretical, and the theoretic sciences, mathematics, physics, and metaphysics, the supreme. These sciences seek to investigate the causes and supreme principles of being, as the incorruptible substances, among them the nature of the first Unmoved Mover, commonly identified as God.

Thus, the theoretic sciences are the highest in dignity and worth. They have this status because investigating the supersensible reality, characterized as immutable and necessary, ending in itself. It is essentially speculative, with no claim to act directly in the contingent world, the world act, whether in the family, tribe or polis.

Thus, theology or metaphysics seeks deeper knowledge attained by speculative reason. Therefore, the first philosophy is the most divine and worthy science of appreciation of all the sciences, because it is investigating the higher genre of being reality, the first and universal causes of being. "Indeed, if there is God, there is no doubt that there is a reality of that type. And there is no doubt that the highest science [metaphysics] should have the purpose of the highest kind of reality. This [the metaphysics], in fact, among all, is the most divine and most honorable” (Met. 2, 983 a; Pegoraro 2007).

In the hierarchy of Aristotelian science, metaphysics is the highest rank. Therefore, the wisdom, as the higher metaphysical knowledge is called, is the most difficult knowledge to be engendered by the wise. If it is the deepest, therefore it is inexhaustible. Its search is unceasing, arising from the research, discussion, and contemplation. In general, the first philosophy seeks knowledge of being as being, that is, the stricter and fuller being, the substance. Otherwise, the substance is the last firmament of being, which receives all the reason to be, expressed by categories or predicaments of being prioritized in the following order: 1 Substance or Essence; 2 Quality; 3 Quantity; 4 Ratio; 5 Action or Act; 6 Passion; 7 Place; 8 Time; 9 Having and 10 Dwelling. It is noteworthy that all these forms of being are restricted to the being of substance. They are always conditions of the substance.

\subsection{The Productive Sciences}

The status of productive sciences, formed by the rhetoric and the poetic, aims to produce a form of knowledge dedicated exclusively to the world of doing, that is, to a knowledge capable of producing certain objects. On the one hand, human action produces no different object; it is the same on the other, the art of making produces a different reality, something artificial, either a work of art, such as a speech or an instrument. The act of producing has "a purpose in relation to something else" (EN VI 2, 1139 b).

Thus, the rhetoric has as its object to discover effective means for the speaker to persuade the listener in different auditoriums on matters pertaining to deliberative, judicial, and celebrative genres. The deliberative used in meetings, aimed at useful and planning the future of the polis; the judiciary, used in courts of law, 
aimed at the fair and talks about the past; the celebrative, used in public services, seeks the beautiful, the good and refers to the present (Ret. I 3, $1358 \mathrm{~b}$ ).

Poetic, on the other hand, has as its object to imitate tragic actions, with ornate language, namely to establish a node that will untie during the theatrical presentation. Its purpose is the art of mimesis, not really describe things happened, which is the activity of the historian, but to recreate and reproduce nature. That is why poetry is more philosophical, because it aims at the universal, while the history, the particular, the fact (Poet. 9, 1451 a).

Thus, a theatrical presentation, in form of tragedy, has the goal of producing a suitable speech that can instill terror and pity in the audience attending the show, referring to things as impossible at first sight, but possible of accomplishment. What was apparently a mystery becomes a capable of understanding (Poet. 6, 1449 b).

\subsection{The Practical Sciences}

The practical sciences, comprised of the economy, ethics, and politics, investigate the reality of the contingent world, particularly changeable history of achievement in the world of acting field. Among all goods expected in the field of action, happiness is the supreme good. And if the Intelligible, which comprises the unmoved mover and the gods, has an enduring nature and is happy forever, human eudaimonia tries to imitate the most of this state of beatitude. And it is the function of the practical sciences, by adjusting the actions and emotions of citizens and through fair laws in the polis, seek to establish a good life, through active is contemplative life.

While in the world of phýsis there is a given order, objectively, the world's prefectures and the ethos seeks to establish a subjective order, incessantly rebuilt. It is the nature of contingent world with its laws, rules, and constitutions, be constantly reworked, re-discussed. While the object of theoretic science is descriptive, leaving things as they are, aimed only to the knowledge of the order of the universe to contemplate it, the practice of science, by contrast, is normative. They aim to meet human action to change it, introducing the possibility of man's conquest of fullness, that is, the balance in human actions by the practice of virtue.

The practical rationality anchored in metaphysics, provides, in the form of diagram or sketch, the general guidelines to do well and the foundations. These guidelines are the first principles of political science, and do not have the consistency of demonstrative rationality and metaphysics. They stem from the tradition of the local ethos, customs of the righteous men, filtered by reason and specifically guided by prudence, practical wisdom which deliberates on the best private means for the virtuous man to act well (eupraxis) and to achieve happiness.

\section{Final Considerations}

Thus, there is a hierarchy in the Aristotle's sense of being. Intrinsic to the reality hierarchy there is a teleological intentionality, not accidental, but inherent to, because without this predisposition the world would be absolute chaos. Similarly, there is an intention to establish teleology in the act moral agent, to give meaning to his existential condition.

Therefore, Aristotle refers to various forms of rationality to explain reality. There are many ways to analyze the being of things, not all reduced to logical-mathematical model, accurate, concise, exact sciences, or model of theoretic sciences, knowledge of the cause and necessity. However, various forms of rationality 
theorized by Aristotle are valid, capable of universalization and communicable (Berti 2002, XVI). After all, being, the real, presents itself in different ways. And each approach is to be expressed a dimension of substance.

\section{Works Cited}

Aristotle. Construction. Greek translation, preliminary study, preambles and notes by Francisco de P. Samaranch. 2nd ed. Madrid, 1967.

---. Metaphysics: Introductory Essay. Greek text with translation and commentary by G. Reale; Greek text with translation to the side. Trans. Marcelo Perine. São Paulo: Loyola, 2002.

---. Ethics to Nicomachus. Trans. M. G. Kury. 4th ed. Brasília: Editora Universidade de Brasília, 2001.

Barnes, Jonathan. Aristotle. Oxford: Oxford University, 1982.

Berti, Enrico. The Reasons of Aristotle. Trans. Dion Davi Macedo. 2nd ed. São Paulo: Loyola, 2002.

Hadot, Pierre. What Is Ancient Philosophy? Trans. Dion Davi Macedo. 3rd ed. São Paulo: Loyola, 2008.

Höffe, Otfried. Aristotle: Introduction. Trans. Robert H. Pich. Porto Alegre: Artmed, 2008.

Pegoraro, Olinto Antonio. “The Verticalization of Metaphysics and the Triangularity of Truth.” Stein, Ernildo (Org.). The City of Men and the City of God. Porto Alegre: EST, 2007. 63-70.

Reale, Giovanni. History of Ancient Philosophy. Trans. Henrique Lima Vaz and Marcelo Perine. São Paulo: Loyola, 1994, V. II.

Ross, Sir David. Aristotle. Trans. Luis F. B. Teixeira. Lisboa: Publicações Dom Quixote, 1987. 